\title{
RUSSIA AND JAPAN IN NORTH KOREA'S DENUCLEARISATION PROCESS: DIVERGING RESPONSES
}

\author{
Geetha Govindasamy
}

\begin{abstract}
Recent North Korean foreign policy has shown dramatic changes. Thus far, Kim Jong Un has met Moon Jae In, Donald Trump and Xi Jinping. These meetings have mostly concentrated on the North Korean denuclearisation process. However, there seems to be a lack of progress in talks. More interestingly, the Russian Federation and Japan have not been privy to discussions on the extent to which North Korea will denuclearise. The article examines if Moscow and Tokyo have a role to play in negotiations. The research finds that while Russia has possibilities in playing a role, Tokyo will be shut out in future discussion simply because Tokyo and Pyongyang have yet to establish formal relations. As an ally, Russia is trusted by North Koreans. It is expected that any form of trilateral economic cooperation between Moscow, Seoul and Pyongyang will forge the way for Russia to play an important role in the denuclearisation process. Conversely, Tokyo's determination to resolve the kidnapping of Japanese citizens' decades earlier by North Korean agents remains an impediment in furthering bilateral relations. It is predicted that Tokyo will play a role in the development of North Korea after Pyongyang agrees to completely denuclearise.
\end{abstract}

Keywords: denuclearisation, North Korea, Russian Federation, Japan, kidnapping

\section{Introduction}

Though North Korean denuclearisation is an on-going process, the lack of progress is quite concerning and therefore offers opportunities for multiple key players to intervene. The Russian Federation and Japan are major players in the Asia Pacific region. However, both have different types of relations with North Korea. While Moscow has diplomatic relations with Pyongyang, Tokyo has been reluctant to do so. Moscow is still viewed as an ally by Pyongyang, but Japan-North Korean relations are more antagonistic due to past aggressions by Japanese colonization of the Korean peninsula for 35 years. The North Korean nuclear programme is a concern for both Russia and Japan. Nonetheless, as a Cold War ally, Russia has more room to negotiate with North Korea than Japan. Without having a trustworthy relationship with Pyongyang, Tokyo seems to be struggling to be a respected player in the negotiations. Consequently, it has to rely on South Korea and the United States to highlight its views on the matter.

The year 2018 has opened the floodgates on discussing the North Korean denuclearisation. In meetings with South Korean President Jae In, Chinese President Xi Jin Ping as well as President of the Unites States (US) Donald Trump, North Korean leader Kim Jong Un has pledged to work towards the "denuclearisation" of the Korean Peninsula. However, multiple reports indicate that Pyongyang is continuing to develop its nuclear 
weapons program. This is not surprising, given that Kim has not made any public promises to halt work on the North's nuclear and missile facilities. Many interpret Kim's commitment to denuclearisation as a promise to immediately surrender or dismantle the country's nuclear arsenal. But thus far, Pyongyang has only given in to certain parameters, such as no nuclear and intercontinental ballistic missile (ICBM) testing. The result is that the US and South Korea are dissatisfied with the lack of progress in getting Pyongyang to even seriously take steps to denuclearise. The fact that Washington has also rejected any suggestions of lifting sanctions against North Korea has exacerbated the situation. North Korea has threatened it will resume its nuclear development if Washington does not change its stance. ${ }^{1}$

Since the US has refused to lift economic sanctions against Pyongyang, North Korea has warned it could revive its Byungjin policy which aims at further strengthening its nuclear arsenal. ${ }^{2}$ Pyongyang is of the opinion that Washington has betrayed the essence of the June summit by making unilateral demands for denuclearisation without taking any reciprocal measures. ${ }^{3}$ In other words, the North is expecting some concessions from the US and its allies. The question remains what is the role or position of Russia or Japan in the denuclearisation process. While South and North Korea are courting Russia economically and politically, Japan is nowhere to be found even as a wanted affiliate when dealing with Pyongyang. Though Kim is ready to meet Japanese Prime Minister, Shinzo Abe, the negative rhetoric against Tokyo by North Korea has not ceased. Barely a day passes without the North Korean state media condemning Japan for what is perceived to be its past colonial crimes. ${ }^{4}$

\section{A Flurry of Summits without Russian and Japanese Involvement}

The year 2018 has seen Kim Jong Un meeting his South Korean counterpart, Moon Jae-in, Donald Trump, and Xi Jinping. However, Kim has yet to meet with Russian President Vladimir Putin and Shinzo Abe. In this new era of North Korea's open door policy, Russia nor Japan have been privy to discussions on North Korea's denuclearisation. Given the position and involvement of Moscow and Tokyo in regional affairs, especially on the Korean peninsula, this is surprising. This brief article argues that the Russian Federation and Japan recognize that they have been side-lined and are now attempting to play a substantial role in managing the issue.

Therefore, it was not surprising when in August of this year, Putin stressed his wish to establish a bilateral dialogue with Kim Jong Un. ${ }^{5}$ When Valentina Matvienko, the speaker of the upper house of the Russian parliament visited Kim in Moscow in September 2018, she remarked that the North Korean leader was eager to meet Putin. ${ }^{6}$ Many analysts expected Kim

\footnotetext{
1 'North Korea Threatens to Resume Nuclear Development if U.S. Doesn't Lift Sanctions.' ABC News, 3 November 2018. Retrieved from https://www.nbcnews.com/news/world/north-korea-threatens-resume-nukedevelopment-over-sanctions-n930761. Retrieved 19 December 2018.

${ }^{2}$ Robert Carlin, 'Pyongyang Warns Again on "Byungjin” Revival, 38 North, 13 November 2018. Retrieved from https://www.38north.org/2018/11/rcarlin111318/. Retrieved 19 December 2018.

${ }^{3}$ Georgy Toloraya, 'From CVID to CRID: A Russian Perspective,' 38 North, 26 December 2018. Retrieved from https://www.38north.org/2018/12/gtoloraya122618/. Retrieved 26 December 2018.

${ }^{4}$ Jamie Tarabay, 'Bad Blood between North Korea and Japan Keeps Abe on the Outs,' CNN News. 28 August 2018. Retrieved from https://edition.cnn.com/2018/08/28/asia/japan-north-korea-relations-intl/index.html. Retrieved 19 December 2018.

${ }^{5}$ Samuel Osborne, 'Vladimir Putin Ready to Meet Kim Jong-un to Discuss 'Urgent Issues', says North Korean State Media,' Independent, 15 August 2018. Retrieved from https://www.independent.co.uk/news/world/asia/vladimir-putin-kim-jong-un-north-korea-russia-meetingliberation-day-a8492441.html. Retrieved 26 December 2018.

${ }^{6}$ Henry Holloway, 'Vladimir Putin Invites Kim Jong-un to Russia as Heavyweights to Meet for First Time Ever,' Daily Star Sunday, 8 September 2018. Retrieved from https://www.dailystar.co.uk/news/latestnews/728382/vladimir-putin-kim-jong-un-russia-north-korea-meeting-nuclear-war-us-donald-trump. Retrieved 12 December 2018.
} 
to meet Putin at the economic forum in Vladivostok in September 2018. However, a delegation of North Korean officials were sent to the forum instead. ${ }^{7}$ A summit between Kim and Putin is expected soon, but the date remains unclear. It can be argued that the Russian objective of wanting to develop the Far Eastern region coincides with Moscow's intention of improving its international image as a responsible stakeholder of the Korean peninsula peace process. A Putin-Kim meeting would certainly enhance Moscow's position as an intermediary for building bridges between Seoul and Pyongyang. In comparison, Koichi Nakano, a Professor of Political Science from Sophia University observes that Japan has been isolated and has very little of 'a role to play except perhaps to pay up once [Donald]Trump finds a deal. 8

Japan's negative relations with North Korea is based on historical issues like the comfort women and biased interpretations of history textbooks, the development of North Korea's nuclear programme which directly threatens the security of the Japanese archipelago and the unresolved issue of North Korean kidnappings of Japanese citizens in the 1970s and 1980s. Nonetheless, Kim Jong Un has shown willingness to meet Shinzo Abe sometime in the future. ${ }^{9}$ Abe's address to the United Nations General Assembly at the end of September 2018 clearly indicated that he is ready 'to break the shell of mutual distrust with North Korea, get off to a new start and meet face to face with Chairman Kim Jong-un.' ${ }^{10}$ Though Abe attended the economic forum in Vladivostok, Kim's absence there made it impossible for the Japanese leader to make any progress in discussing issues of concern. Therefore, if a summit does take place between Kim and Abe in 2019, the meeting will certainly not only address North Korean denuclearisation but also Japan's own determination to solve bilateral issues, namely the kidnapping of its citizens.

\section{Russia- North Korea Bilateral Relations}

This section begins with the examination of Russian interests in North Korea. It is pertinent to understand the historical background as to why Russia desires to play a key role as well as the extent to which it can be an effective interlocutor in denuclearisation talks. Relations between Russia and North Korea are based on Cold War legacy and diplomatic cooperation. Russia shares a 17 kilometres border with North Korea. Russia's ties with North Korea date from the late-1940s since before the creation of North Korea in 1948. Relations saw fluctuations based on changes in the international system as well as Russian leaderships. After the Cold War ended in the early 1990s, the then-President Boris Yeltsin devoted more attention towards the West as well as South Korea instead of North Korea. Partly, this was because Russia was struggling with its own economic problems after the collapse of the Soviet Union.

However, with the breakthrough in inter-Korean relations in June 2000 between Kim Dae Jung and Kim Jong Il, President Vladimir Putin became the first Russian leader to visit Pyongyang in July of the same year. The visit can be interpreted as Russia's way of establishing itself as an influential player in the Asia Pacific region (ABC News, 2000). During the meeting, Putin suggested that Russia, South Korea, as well as the United States, China and Japan should

\footnotetext{
${ }^{7}$ Henry Holloway, 'Vladimir Putin Invites Kim Jong-un to Russia as Heavyweights to Meet for First Time Ever,' 8 September 2018.

8 'Japan Increasingly Isolated as North Korea Diplomacy Progresses,' Voa News, 4 April 2018. Retrieved from https://www.voanews.com/a/us-japan-summit/4331731.html. Retrieved 1 August 2018.

9 'Shinzo Abe and Kim Jong-un Could Meet after North Korean Leader Says He's Willing,' South China Morning Post, 14 June 2018. https://www.scmp.com/news/asia/diplomacy/article/2150729/shinzo-abe-and-kimjong-un-could-meet-after-north-korean-leader. Retrieved 12 December 2018.

${ }^{10}$ Adam Whitnall, 'Japan's Shinzo Abe Says He Could meet Kim Jong-un Face-to-face and 'Break the Shell of Distrust' with North Korea,' The Independent, 26 September 2018. Retrieved from https://www.independent.co.uk/news/world/asia/japan-shinzo-abe-kim-jong-un-meeting-north-korea-summitsouth-a8555316.html.
} 
work with North Korea to resolve the nuclear issue (ABC News, 2000). In so doing, Putin managed to revive deteriorating Pyongyang-Moscow relations. But relations worsened when Putin was forced to support United Nations (UN) Security Council Resolution 1695 in July 2006, condemning a North Korean missile test. A few years later, Russian President Dmitry Medvedev endorsed UN sanctions after the North Korean nuclear test on 25 May 2009. Bilateral relations saw massive improvements when Putin again became the Russian President in 2012. Interestingly, on September 2012, Putin decided to write off $90 \%$ of North Korea's $\$ 11$ billion historic debt to Russia with the expectation that it will advance bilateral economic cooperation and expand Russia's influence in East Asia. ${ }^{11}$ As a result of this generous gesture, bilateral relations continued to progress. In 2017, Pyongyang's state-controlled news agency, KCNA, listed Russia at the top of the list of countries friendly towards North Korea. ${ }^{12}$

It is quite clear that Putin is seeking opportunities to advance Russian economic interests on the Korean Peninsula. Moscow's pursuit of closer economic ties with North Korea constitutes part of its foreign policy of 'turning to the east.' ${ }^{13}$ Thus far, Russian investments in the North Korean economy has assisted Kim regime's survival. Although, in reality Russia's ability to benefit economically from North Korea is rather limited, Putin is attempting to deepen Moscow's alliance with Pyongyang in order to cement Russia's role as a patron in promoting long-term peace on the Korean peninsula. In line with this, Russian technical expertise is being exposed to North Korean workers at the Rajin-Khasan railway, which links Russia to the Korean peninsula. South Korea was supposed to be the third party in the Rajin-Khasan railway project but it withdrew in March 2016 following North Korea's fourth nuclear test in 2016. ${ }^{14}$ Despite the setback, Moscow is continuing the project as one way to strengthen its relations with the North Korean regime. Russian policymakers hope now that inter-Korean relations are on the mend, South Korea will re-join the Rajin-Khasan railway project. There is always the possibility that South Korea might re-join the Rajin-Khasan project as it is exempt from UN sanctions imposed on Pyongyang. ${ }^{15}$ A trilateral cooperation between Moscow, Pyongyang and Seoul would surely increase trust and security for North Korea. If the project succeeds in attracting South Korean participation, Russia would be the first major power to be involved in an economic project with both Koreas. ${ }^{16}$ For Russia's Far East, its next-door neighbours, especially both Koreas are natural partners in its development efforts.

Under Kim Jong Un, Russia seems to feature as an advantageous ally in Pyongyang's foreign policy. Russia maintains air, rail, sea, and internet linkages with the North. It is the second most important economic partner to North Korea after China. ${ }^{17}$ Russia's assistance in

\footnotetext{
${ }^{11}$ M Dyakina, and L. Kelly, 'Russia Writes off 90 Percent of North Korea's Debt,' Reuters, 18 September 2012. Retrieved from https://www.reuters.com/article/us-korea-north-debt/russia-writes-off-90-percent-of-northkoreas-debt-idUSBRE88H0NH20120918.

${ }^{12}$ L. Todd Wood, 'North Korea's BFF is Russia,' The Washington Post, 7 February 2017. Retrieved from https://www.washingtontimes.com/news/2017/feb/7/north-korea-puts-russia-atop-friendly-countries-li/. Retrieved 1 December 2018.

${ }^{13}$ Andrei Kozinets \& James Brown, 'Russia's 'Turn to the East', East Asian Forum, 7 October 2006. Retrieved from http://www.eastasiaforum.org/2016/10/07/russias-turn-to-the-east/. Retrieved 2 November 2018.

${ }^{14}$ J. S. Yoe, 'Lifting sanctions on Rajin-Khasan Project Key to Economic Cooperation with Russia NK,' Korea Herald, 10 July 2018. Retrieved from http://www.koreaherald.com/view.php?ud=20180706000494. Retrieved 1 December 2018.

${ }^{15}$ J. S. Yoe, 'Lifting sanctions on Rajin-Khasan Project Key to Economic Cooperation with Russia NK,' 10 July 2018.

${ }^{16}$ D. Danudoro, 'New Developments in Russia South Korea Relations,' Leksika, 19 August 2018. Retrieved from http://www.leksika.org/tacticalanalysis/2018/8/19/new-developments-in-russia-south-korea-relations. Retrieved 11 December 2018.

${ }^{17}$ M. Chansoria, 'Russia, China Power Games Prop Up North Korea’s Nuclear Brinkmanship,' Japan Forward, 19 April 2018. https://japan-forward.com/russia-china-power-games-prop-up-north-koreas-nuclearbrinkmanship/. Retrieved 2 September 2018.
} 
helping to provide North Korea to attain hard currency through various means is well documented. Since Pyongyang faces energy disruptions due to sanctions, Russia has played a crucial role in providing oil to North Korea. It is reported that Siberian oil companies sell fuel to North Korea which is then processed in chemical plants and later Pyongyang exports the item to China. ${ }^{18}$ Conversely, squeezed by sanctions, North Korea has also benefitted from sending guest workers to construction projects in many parts of Russia. The US State department estimates North Korea earns around $\$ 150-\$ 300$ million annually by providing guest workers to Russia. ${ }^{19}$ While the North gains much needed hard currency, Putin benefits from cheap North Korean labour in developing the Far Eastern region. ${ }^{20}$

\section{Japan- North Korea Bilateral Relations}

The Japanese occupation of the Korean Peninsula for 35 years between 1910 and 1945 resulted in negative implications for Tokyo's bilateral relations with Pyongyang. Though in 1965, Tokyo and Seoul established diplomatic ties due to economic, political and security interests of the East Asian region, Tokyo's relations with Pyongyang is still unofficial and far under developed. The relationship is overshadowed by unresolved political issues. Bilateral relations showed improvements when Japanese Prime Minister Koizumi (2001-2006) visited Pyongyang to meet Kim Jong Il on 17 September 2002 and 22 May 2004. However, these visits failed to witness any dramatic changes in bilateral relations as they were hampered by two main factors - the development of North Korea's missile and nuclear missiles and the kidnappings of Japanese citizens by North Korean agents in the 1970s and 1980s.

Another obstacle Tokyo faces is the issue of damages and compensation for past Japanese occupation of the Korean peninsula. North Korea has long demanded Japan pay compensation for damages caused by a brutal colonial administration between 1910 and 1945 . Japan's stance is that the compensation issue has been resolved. However, the matter will emerge once Pyongyang, Seoul and Washington declare the end of the Korean War (1950-53). South and North Korea intend to end the Korean War officially as soon as possible. The ending of the war can only take place with support from the US. Because Japan was not involved in the Korean War, it has had no role in discussions on terminating the war. However, it can be assumed that Japan will be called upon by Washington and Seoul to contribute to North Korea's future redevelopment once more official relations are established. The payment to North Korea may even contribute towards the removal activities of North Korean nuclear weapons. Hence, if Japan wants to play a role in ending the Korean War, it will surely have no choice but to offer some financial support to North Korea. Pyongyang may accept the gesture as payment for past 'war crimes.' 21

At this point in time, Tokyo has no choice but to assist. The failure to resolve North Korea's nuclear issue and the kidnapping of Japanese citizens has led to tense bilateral ties for decades. Until a solution can be found, it can be assumed that Tokyo will not officiate its relations with Pyongyang. Currently, the General Association of Korean Residents in Japan (Chongryon) plays the role of unofficial North Korean representative in Japan. This is not surprising because Chongryon are ethnic Koreans living in Japan whose members support the North Korean government. Given that North Korea's relationship with Washington and Seoul

\footnotetext{
18 'Samuel Ramani, Russia's Love Affair with North Korea,' The Diplomat, 13 February 2017. https://thediplomat.com/2017/02/russias-love-affair-with-north-korea/. Retrieved 13 October 2018.

19 'Russia Allows Thousands of North Korean Workers In,' VoaNews, 3 August 2018. Retrieved from https://www.voanews.com/a/report-russia-north-korean-workers/4512027.html. Retrieved 5 September 2018.

${ }^{20}$ Samuel Ramani, 'Russia's Love Affair with North Korea,' 13 February 2017.

21 'Japan Ready to Share IAEA costs on North Korea Nuke Disarmament,' Asahi Shimbun, 16 June 2018, Retrieved from http://www.asahi.com/ajw/articles/AJ201806160043.html. Retrieved 28 July 2018.
} 
is getting closer, Shinzo Abe knows he has to orchestrate a direct meeting with Kim Jong Un. Otherwise, Tokyo will have to forever rely on Washington and Seoul to pursue its interests on the Korean peninsula. This situation is dangerous as Tokyo's bilateral ties with Seoul is often tense. In addition, the absence of a concrete East Asian policy by the Trump administration makes the Abe government feel more insecure. Consequently, it is not surprising that Abe's growing unease over Trump's 'America First' policy has encouraged him to take on a more pro-active stand on dealing with North Korea.

In terms of Japanese security concerns, North Korea became a cause of concern with the emergence of the first nuclear crisis between Washington and Pyongyang in 1994 and the 1998 North Korean missile test launch that flew of over the Japanese islands. In addressing the issue, from 2004 onwards, Tokyo worked closely with the US, China, Russia and South Korea within the context of the Six Party Talks for the purpose of dismantling North Korea's nuclear program. However, it was unfortunate that the Japanese strategy was always to complement nuclear discussions with that of the issue of the kidnapping of Japanese citizens in the 1970s and 1980, something that contrasted with the objective of the Six Party Talks. Since the kidnapping issue was given the same importance as the termination of the North Korean nuclear program, Tokyo's influence in the negotiations became limited as it was not in line with other members' outlook. ${ }^{22}$ Moreover, Tokyo's troubles doubled when the Six-Party Talks itself collapsed in 2009. Japan and the international community were deprived of a platform in finding a solution to North Korea's weapons programme.

More importantly, the failure contributed to the rapid progress of North Korean defence capabilities. Currently, North Korea's short and medium-sized missile weapons are capable of destroying Japan. Although with the US assistance, Japan has developed a two-layered ballistic missile defence system, there is no guarantee that it can track every North Korean missile. ${ }^{23}$ Consequently, Abe became one of the strongest Asian leaders to support Trump's 2017 'Maximum Pressure' campaign, which essentially tried to isolate North Korea by draining Pyongyang's resources originating from abroad that could be used for provocative behaviour. Tokyo was also in favour of stepping up sanctions on North Korea, more so after the country's sixth and most powerful nuclear test on 3 September 2017. North Korea reacted to Japan's support of US maximum pressure campaign by firing a Hwasong-12 missile over the northern Japanese island of Hokkaido on 15 September 2017. Just a day earlier, Pyongyang remarked that Japan "should be sunken into the sea" with a nuclear bomb. ${ }^{24}$ In response, Japan's Self Defence Forces participated in exercises with three American carriers and the Indian Navy in the Sea of Japan in 2017. ${ }^{25}$ By the end of 2017, such exchanges of provocative behaviour from both sides worsened Tokyo-Pyongyang relations. Clearly, the Abe administration had a trust deficit when it involved North Korea. Therefore, Abe's support for Trump's campaign is directly a result of understanding that the Kim regime will not change its course without

\footnotetext{
${ }^{22}$ Michael R. Auslin, 'Japanese Perspectives on the Six-party Talks and the North Korean Nuclear Crisis.' In Tomorrow's Northeast Asia, Joint US-Korea Academic Studies, Volume 21, 2011, Korea Economic Institute, Korea Institute for International Economic Policy and School of International Service at American University. pp. 195-206. Retrieved from http://keia.org/sites/default/files/publications/jukas_2011-11_auslin.pdf. Retrieved 1 August 2018.

23 'Russia Allows Thousands of North Korean Workers In,' 3 August 2018.

${ }^{24}$ Anna Fifield and Dan Lamothe, 'North Korea fires another missile over Japan, triggering warnings and condemnation, 'The Washington Post, 15 September 2017. Retrieved from https://www.washingtonpost.com/world/north-korea-fires-another-missile-from-near-pyongyang-reportedlyover-japan/2017/09/14/9d465988-9999-11e7-a527-3573bd073e02_story.html?utm_term=.5e3c455c6dd2. Retrieved 3 August 2018.

25 Jessie Johnson, 'MSDF holds rare trilateral exercises with Indian and US vessels in Sea of Japan,' Japan Times, 7 November 2017. Retrieved from https://www.japantimes.co.jp/news/2017/11/07/national/msdf-holdsrare-trilateral-exercises-indian-u-s-vessels-sea-japan/\#.XCWynlwzbcs. Retrieved 7 August 2018.
} 
applying sufficient pressure. At the same time, such support turned Pyongyang more hostile towards the Abe government.

\section{Russian and Japanese Involvement in the North Korean Denuclearization Process}

Russia has long been involved in regional multilateral attempts in persuading North Korea to denuclearize. It was one of the six countries involved in the now-defunct Six-Party Talks process. The Six-Party talks which aimed to negotiate with Pyongyang concerning its nuclear weapons programme involved North Korea, South Korea, Japan, China, Russia and the United States. However, the talks were suspended in 2009 at Pyongyang's initiative. When situation on the peninsula worsened, Russia, China and South Korea, spoke out in favour of resuming talks within a multilateral context like that of the Six Party Talks.

President Putin has openly publicized that Russia wants to be an integral part of any comprehensive agreement on the Korean Peninsula. Consequently, Moscow supported Beijing's idea of a 'dual freeze' initiative in July 2017. ${ }^{26}$ Under this scheme, Moscow and Beijing proposed a simultaneous freeze of missile and nuclear activities by North Korea and large-scale joint exercises by the US and South Korea. Further, it was suggested that a suitable peace and security mechanism be created to iron out sensitive issues through dialogue and consultations. Consequently, such a mechanism was expected to lead to future normalisation of relations between the countries in question.

In countering North Korea's missile and nuclear programmes, both Moscow and Beijing opposed any extra military presence or provocations on the Korean. ${ }^{27}$ In order to promote trust, Russia emphasized that Pyongyang's interests and security concerns should also be taken into consideration. Russia not only wants to achieve North Korea's denuclearisation but also assist in establishing a peace treaty. Russia like China is in a unique position in having relations with both Koreas which renders it a mutually trusted party in the context of interKorean mediation. More importantly, Moscow and Beijing firmly believe that phased measures are more conducive rather than waiting for complete North Korean denuclearisation. To both these key players, a multilateral framework would be the best way to create an atmosphere of mutual trust when dealing with North Korea.

Unfortunately, the momentum to decrease tensions on the Korean peninsula became disrupted when North Korea launched a nuclear test in September 2017 which forced Russia and China to support sanctions adopted by the United Nations Security Council. As a result, relations between Pyongyang and Moscow became strained. Russia hurriedly dispatched a delegation of parliament members to Pyongyang for a three day visit between 27 November and 1 December 2017. ${ }^{28}$ During the visit, members of Russian parliament discussed possible solutions to denuclearization with the North Koreans who were already suffering from a barrage of international sanctions. The leader of the Russian delegation Kazbek Taysayev

\footnotetext{
26 'Germany supports Russian-Chinese 'double freeze' plan for North Korea crisis - FM Gabriel,' RT.com, 16 August 2017. Retrieved fromhttps://www.rt.com/news/399775-germany-supports-freeze-korea/. Retrieved 7 August 2018.

${ }^{27}$ peninsula (The Ministry of Foreign Affairs of the Russian Federation, 2017)

${ }^{28}$ E. Furukawa,' Russia Edges in as Key Power Broker with North Korea,' Nikkei Asian Review, 4 December 2017 https://asia.nikkei.com/Spotlight/North-Korea-crisis-2/Russia-edges-in-as-key-power-broker-with-NorthKorea2. Retrieved 2 August 2018.
} 
reported that North Korea viewed Russia as a potential intermediary in any talks. ${ }^{29}$ In addition Vitaliy Pashin, another member of the Russian parliamentary delegation commented,

\section{The Democratic People's Republic of Korea is ready to conduct negotiations with the U.S. in conditions of parity and with Russia's participation as a third party. ${ }^{30}$}

Such parliamentarian “diplomacy' was not new as the Chairman of the State Duma Viacheslav Volodin had already met with his South Korean counterpart as early as June 2017. This indicates that Russia consciously has been trying to position itself as a key player in the Korean peninsula peace process despite the fact North Korea refused to endorse its 'dual freeze' plan. In May 2018, ahead of the proposed Kim and Trump meeting, Kim Jong Un met Russia's Foreign Minister Sergey Lavrov. The meeting was significant as this was the first time the North Korean leader met with a top ranking Russian official. The timing of the meeting was seen as a move by Moscow to guarantee its voice was heard in Pyongyang's diplomatic meetings with the US and South Korea. According to Anthony Rinna, a specialist in KoreaRussia relations at the Sino-NK website, Kim's meeting with Lavrov was designed to acquire backing to push the US to make concessions. ${ }^{31}$ The Russian Foreign Minister did not disappoint when he called for lifting of sanctions and implied that a comprehensive solution to the North's nuclear problem will not materialize without the lifting of sanctions. ${ }^{32}$

Besides cooperating with China, Russia is moving head in strengthening its relations with South Korea. Russian policymakers understand that an improvement in bilateral relations could increase Moscow's influence not only in the denuclearisation talks but also in the Asia Pacific region. The coinciding of Putin's "new eastern policy" and Moon's "new northern policy" is an excellent time for Moscow-Seoul relations to flourish. Given this, Putin and Moon Jae In met in Moscow in June 2018. During the meeting Russia indicated it wanted to attract more South Korean investments to its Far Eastern region and Moon requested for Russian support for the denuclearisation process on the Korean peninsula. Both leaders agreed to promote peace on the Korean peninsula through some form of trilateral cooperation between Moscow, Seoul and Pyongyang. According to a report from the Blue House, during the meeting Moon remarked that,

I believe South Korea and Russia are key cooperation partners on the Korean peninsula and the Eurasian continent and therefore place great importance on strategic cooperation with Russia as an important part of our government's foreign and security policies. ${ }^{33}$

\footnotetext{
29 D. Sharkov, North Korea Sanctions won't Defeat Kim Jong Un, Says Russian Lawmakers who Visited Pyongyang, Newsweek, 1 December 2017. https://www.newsweek.com/north-korea-sanctions-wont-defeat-kimjong-un-says-russian-delegation-728096. Retrieved 5 December 2018.

${ }^{30}$ D. Sharkov, 'North Korea Sanctions won't Defeat Kim Jong Un, Says Russian Lawmakers who Visited Pyongyang,' 1 December 2017.

${ }^{31}$ T. Balmforth and J. Smith, 'Lavrov Invites Kim to Russia as Moscow Makes Pyongyang Play,' Reuters, 31 May 2018. https://www.reuters.com/article/us-northkorea-missiles-lavrov-kim/lavrov-invites-kim-to-russia-asmoscow-makes-pyongyang-play-idUSKCN1IW0SH. Retrieved 4 December 2018.

32 S. George, 'Russian foreign minister meets Kim Jong Un, Calls for Lifting of Sanctions,' CNNNews, 3 May 2018. Retrieved from https://edition.cnn.com/2018/05/31/asia/sergey-lavrov-north-korea-intl/index.html. Retrieved 3 September 2018.

33 'Putin, Moon agree to support efforts for full denuclearisation,' The Straits Times, 23 June 2018. Retrieved from https://www.straitstimes.com/asia/east-asia/putin-moon-agree-to-support-efforts-for-full-denuclearisation. Retrieved 3 September 2018.
} 
With inter-Korean relations showing signs of improvement, Putin and Moon are hoping that joint economic and infrastructure projects can be promoted when sanctions are lifted so that South Korea and Russia will be linked through North Korea. Both leaders discussed possible cooperative projects in the fields of electricity, gas and railways in between North Korea, Russia and South Korea. ${ }^{34}$ Since large scale infrastructure projects are deemed as one way of bringing peace to East Asia, it is likely that the Rajin-Khasan railway project will see South Korean participation in the near future. More importantly North Korea will likely be part of the construction of a Trans Korean pipeline carrying Russian gas to South Korea via North Korea. ${ }^{35}$ If these investments do come to fruition, Russia can fulfil its goal of acting as a mediator between Pyongyang and Seoul in denuclearisation negotiations.

In comparison to Russia's active role in trying to become an effective mediator in the denuclearisation negotiations, Japan has had little success in infiltrating talks between Pyongyang, Washington and Seoul. For now, Tokyo categorically has no standing whatsoever in the current attempts to denuclearise North Korea. However, if Abe supports the dual freeze plan by China and Russia, it will provide Tokyo with a voice in negotiations. The idea is to have a multilateral framework with the United States, China, Japan, Russia, South Korea and North Korea as members. Different from the Six-Party Talks, a third party like the United Nations or some other regional mechanism can be the mediating factor on Pyongyang's nuclear activities.

Since the US has rejected the dual freeze plan, Abe's silence on the matter indicates that he will not defy the Trump administration. The other option that will possibly enable Japan to play a role is by being a financial donor to North Korea. To a large extent, Seoul and Washington need Japan to contribute financially in the eventual development of North Korea once Pyongyang truly takes steps to denuclearise. Japan itself will hold back any financial incentives till its concerns - the nuclear, missile and abduction issues are resolved. ${ }^{36}$ Now that North Korea has become a 'nuclear' nation, Kim Jong Un has now turned towards developing the economy. To develop all its special economic zones, Kim needs investments from international investors, especially in improving the outdated North Korea's infrastructure, including strengthening energy grids and transportation systems. So any Japanese financial assistance will certainly provide Kim with impetus to develop his economy. Japan can consider the insertion of financial assistance as a form of compensation for its colonial past. For example, during the 1965 negotiations to establish formal relations, Tokyo paid war reparations to Seoul. South Korea received a total of $\$ 800$ million from Japan which included grants as well as government and private commercial loans. ${ }^{37}$ At that time, South Korean President Park Chung Hee used the payment to develop the South Korean economy and infrastructure. Due to decades of hostility in bilateral relations, Japan has yet to pay North Korea directly any war reparations. According to the Japan Times,

Full-blown normalization between Japan and North Korea would ultimately be comparable to the 1965 agreement between Seoul and Tokyo to re-establish diplomatic ties. That deal saw Seoul receive some $\$ 800$ million in "economic

\footnotetext{
34 'Putin, Moon agree to support efforts for full denuclearisation,' 23 June 2018.

35 A. Cohen, 'Putin Uses North Korea Summit to Make Energy Moves.' Forbes, 25 June 2018. Retrieved from https://www.forbes.com/sites/arielcohen/2018/06/25/putin-uses-north-korea-summit-to-make-energymoves/\#47dd60b571d3. Retrieved 6 September 2018.

36 Jessie Johnson, 'North Korea needs cash. Japan has it. Can a deal be made?' The Japan Times, 1 July 2018. Retrieved from https://www.japantimes.co.jp/news/2018/07/01/national/politics-diplomacy/japan-north-koreascash-cow/\#.XCW3LFwzbcs. Retrieved 23 August 2018.

37 '50 years after Korea-Japan pact, some issues won't go away,' Korea Joong Ang Daily, 23 June 2015.

Retrieved from http://koreajoongangdaily.joins.com/news/article/article.aspx?aid=3005725. Retrieved 12 August 2018.
} 
assistance." By some projections this could deliver a compensation package to the North today of anywhere between $\$ 5$ billion and $\$ 10$ billion - a sizable amount for the relatively weak North Korean economy. ${ }^{38}$

Evidently if normalization is realized, Pyongyang expects Tokyo to provide financial assistance of 20 to 50 billion dollars. ${ }^{39}$ Though Tokyo-Pyongyang's bilateral relations have yet to reach any level of normalcy, as a first step, the Japanese government could still channel some funds as a form of financial assistance for selected North Korean economic projects. Tokyo can even invest in one of the joint venture projects that Russian North Korea are involved in. Such a gesture would certainly build bilateral trust and confidence. However, it must be noted that whatever decision the Japanese government chooses, it needs support from its citizens. Abe is in a dilemma because he was appointed with the promise of promoting a firm policy against North Korea. However, Kim Jong Un's policy change has forced Abe to adopt a more flexible strategy against Pyongyang. In addition, Abe understands that any action must be in concert with the American, Chinese, and South Korean aspirations. Nonetheless, by offering limited economic aid to Pyongyang, Abe will at least be able to generate influence and may also be able to move forward in resolving the kidnapping issue. Past history shows that Japanese citizens have no trust in negotiations with North Korea. They are relatively unhappy when financial aid or concession is channelled to Pyongyang without finding a solution in resolving security issues. But, the improvement of Tokyo's relationship with Pyongyang is vital to Japanese security. Any failure to bridge the relationship with Pyongyang will certainly have a political impact on Japan's role in the denuclearisation process, even if it is only an indirect one.

\section{Conclusion}

Six months after the Singapore Summit, there is a distinct lack of progress on North Korean denuclearisation. The Trump administration seems to be weakening in its maximum pressure policy, in particular cancelling military exercises with South Korea. ${ }^{40}$ In fact Moon has accelerated efforts at reconciliation with North Korea and more worryingly, continues to court global support for a reduction in sanctions even before Pyongyang takes any efforts in denuclearising. ${ }^{41}$ All in all, this indicates that the bilateral partnership between Seoul, and Washington has failed to dismantle North Korean nuclear programme. Hence, a multilateral solution is probably the best way to deal with Kim Jong Un. The involvement of various parties probably would be included in different stages in negotiations. Hence, Russia and Japan can play a substantial role, albeit at different stages of the process.

Russia is desperate to improve its international image. The annexation of Crimea in 2014 and the fact that many believe that the Russians meddled in the 2016 American presidential elections have severely damaged Moscow's international profile. Increased

\footnotetext{
${ }^{38}$ Jessie Johnson, 'North Korea needs cash. Japan has it. Can a deal be made?' The Japan Times, 1 July 2018. Retrieved from https://www.japantimes.co.jp/news/2018/07/01/national/politics-diplomacy/japan-north-koreascash-cow/\#.XCW3LFwzbcs. Retrieved 23 August 2018.

39 'Japan offers North Korea summit, Pyongyang discussing meetings with Japan: Asahi,' Reuters, 29 March 2018. Retrieved from https://www.reuters.com/article/us-northkorea-japan/japan-offers-north-korea-summitpyongyang-discussing-meetings-with-japan-asahi-idUSKBN1H43E9. Retrieved 1 July 2018.

${ }^{40}$ Lara Seligman and Robbie Gramer, 'Few Signs of Progress on Denuclearization as U.S., South Korea Cancel Another Major Military Exercise,' Foreign Policy, 19 October 2018. Retrieved from https://foreignpolicy.com/2018/10/19/few-signs-of-progress-on-denuclearization-as-us-south-korea-cancelanother-military-exercise-north-korea-kim-trump/. Retrieved 19 December 2018.

${ }^{41}$ Kim Jaewon, 'Moon seeks Europe's backing for easing sanctions on North Korea,' Nikkei Asian Review, 15 October 2018. Retrieved https://asia.nikkei.com/Spotlight/N-Korea-at-crossroads/Moon-seeks-Europe-sbacking-for-easing-sanctions-on-North-Korea. Retrieved 12 December 2018.
} 
contacts between top ranking Russian officials and North Korea is evidence that Moscow does not want to be side-lined in the denuclearisation process.

Russia is a trustworthy partner to both Koreas. It cannot be denied that Russia's strong economic ties with North and South Korea make it a vital player in negotiations. North Korea views Russia as an honest broker due to its longstanding bilateral relationship. More importantly, Russia together with China has been advocating that all parties concerned take into account North Korea's concerns. More importantly, Russia, like South Korea wants sanction on North Korea to be eased. Though the US has accused Russia of wide-ranging violations of the sanctions imposed on North Korea, it is possible that with Moscow's growing ties with Seoul and Pyongyang, the US might eventually want to engage with Russia. When Putin eventually meets Kim Jong Un, it is likely that Pyongyang will request for greater support against what is perceived as American unilateralism. Its more than likely Putin will support Kim and that will provide the right motivation for Russia to become an effective mediator on the Korean peninsula. In so doing, Russia will not only emerge as a major powerbroker in the Asia-Pacific region but its international image will be one of a responsible major power.

In comparison, Japan has a long way to go before it can play an honest role in the North Korean denuclearisation process. Historical animosity between Tokyo and Pyongyang makes it extremely difficult to get over the trust deficit that exist. Unless Japan begins to support Russia and China to solve the denuclearisation issue through a multilateral forum by defying the US, it is almost impossible for Tokyo to have a voice in negotiations. Tokyo probably would start playing a role when and if a peace treaty is signed to end the Korean War. It is predicted that financial assistance from Japan would certainly contribute to the eventual growth of North Korea. Such financial assistance would provide relative security assurances for North Korea which may very well prompt Pyongyang to accelerate the denuclearisation process. At the time of this writing, the Kim administration has yet to offer a possible date for a Abe-Kim meeting. The delaying tactic is an indication that Japan does not feature highly in the current North Korean foreign policy.

\section{Selected References}

'50 years after Korea-Japan pact, some issues won't go away,' Korea JoongAng Daily, 23 June 2015. Retrieved from http://koreajoongangdaily.joins.com/news/article/article.aspx?aid=3005725. Retrieved 12 August 2018.Auslin, Michael R., 'Japanese Perspectives on the Six-party Talks and the North Korean Nuclear Crisis.' In Tomorrow's Northeast Asia, Joint US-Korea Academic Studies, Volume 21, 2011, Korea Economic Institute, Korea Institute for International Economic Policy and School of International Service at American University, pp. 195-206. Retrieved from http://keia.org/sites/default/files/publications/jukas_2011-11_auslin.pdf. Retrieved 1 August 2018.

Balmforth, T. and Smith, J. 'Lavrov Invites Kim to Russia as Moscow Makes Pyongyang Play.' Reuters, 31 May 2018. Retrieved from https://www.reuters.com/article/us-northkoreamissiles-lavrov-kim/lavrov-invites-kim-to-russia-as-moscow-makes-pyongyang-playidUSKCN1IW0SH.

Carlin, Robert, 'Pyongyang Warns Again on “Byungjin” Revival,' 38 North, 13 November 2018. Retrieved from https://www.38north.org/2018/11/rcarlin111318/. Retrieved 19

December 2018.

Chansoria, M., 'Russia, China Power Games Prop Up North Korea's Nuclear Brinkmanship,' Japan Forward, 19 April 2018. Retrieved from https://japan-forward.com/russia-chinapower-games-prop-up-north-koreas-nuclear-brinkmanship/. 
Cohen, A., 'Putin Uses North Korea Summit to Make Energy Moves.' Forbes, A. 25 June 2018. Retrieved from https://www.forbes.com/sites/arielcohen/2018/06/25/putin-uses-northkorea-summit-to-make-energy-moves/\#47dd60b571d3.

Danudoro, D., 'New Developments in Russia South Korea Relations,' Leksika, 19 August 2018. Retrieved from http://www.leksika.org/tacticalanalysis/2018/8/19/new-developmentsin-russia-south-korea-relations.

Dyakina, M and Kelly, L., 'Russia Writes off 90 Percent of North Korea's Debt,' Reuters, 18 September 2012. Retrieved from https://www.reuters.com/article/us-korea-north-debt/russiawrites-off-90-percent-of-north-koreas-debt-idUSBRE88H0NH20120918.

Fifield, Anna and Lamothe, Dan, 'North Korea fires another missile over Japan, triggering warnings and condemnation,' The Washington Post, 15 September 2017. Retrieved from https://www.washingtonpost.com/world/north-korea-fires-another-missile-from-nearpyongyang-reportedly-over-japan/2017/09/14/9d465988-9999-11e7-a527-

3573bd073e02_story.html?utm_term=.5e3c455c6dd2. Retrieved 3 August 2018.

Furukawa, E., 'Russia Edges in as Key Power Broker with North Korea,' Nikkei Asian Review, 4 December 2017. Retrieved from https://asia.nikkei.com/Spotlight/North-Koreacrisis-2/Russia-edges-in-as-key-power-broker-with-North-Korea2.

'Germany supports Russian-Chinese 'double freeze' plan for North Korea crisis - FM Gabriel,' RT.com, 16 August 2017. Retrieved from https://www.rt.com/news/399775germany-supports-freeze-korea/. Retrieved 7 August 2018.

George, S., 'Russian foreign minister meets Kim Jong Un, Calls for Lifting of Sanctions,' CNNNews, 31 May 2018. Retrieved from https://edition.cnn.com/2018/05/31/asia/sergeylavrov-north-korea-intl/index.html.'Japan offers North Korea summit, Pyongyang discussing meetings with Japan: Asahi,' Reuters, 29 March 2018. Retrieved from https://www.reuters.com/article/us-northkorea-japan/japan-offers-north-korea-summitpyongyang-discussing-meetings-with-japan-asahi-idUSKBN1H43E9. Retrieved 1 July 2018. Holloway, Henry, 'Vladimir Putin Invites Kim Jong-un to Russia as Heavyweights to Meet for First Time Ever,' Daily Star Sunday, 8 September 2018. Retrieved from https://www.dailystar.co.uk/news/latest-news/728382/vladimir-putin-kim-jong-un-russianorth-korea-meeting-nuclear-war-us-donald-trump. Retrieved 12 December 2018.

'Japan Ready to Share IAEA costs on North Korea Nuke Disarmament,' Asahi Shimbun, 16 June 2018, Retrieved from http://www.asahi.com/ajw/articles/AJ201806160043.html.

Retrieved 28 July 2018.

'Japan Increasingly Isolated as North Korea Diplomacy Progresses,' Voa News, 4 April 2018. Retrieved from https://www.voanews.com/a/us-japan-summit/4331731.html. Retrieved 1 August 2018.

Johnson, Jessie, 'North Korea needs cash. Japan has it. Can a deal be made?' The Japan Times, 1 July 2018. Retrieved from

https://www.japantimes.co.jp/news/2018/07/01/national/politics-diplomacy/japan-northkoreas-cash-cow/\#.XCW3LFwzbcs. Retrieved 23 August 2018.

Johnson, Jessie, 'MSDF holds rare trilateral exercises with Indian and US vessels in Sea of Japan,' Japan Times, 7 November 2017. Retrieved from https://www.japantimes.co.jp/news/2017/11/07/national/msdf-holds-rare-trilateral-exercisesindian-u-s-vessels-sea-japan/\#.XCWynlwzbcs. Retrieved 7 August 2018.

Kim Jaewon, 'Moon seeks Europe's backing for easing sanctions on North Korea,' Nikkei Asian Review, 15 October 2018. Retrieved from https://asia.nikkei.com/Spotlight/N-Koreaat-crossroads/Moon-seeks-Europe-s-backing-for-easing-sanctions-on-North-Korea. Retrieved 12 December 2018. 
Kozinets, Andrei \& Brown ,James, 'Russia's 'Turn to the East', East Asian Forum, 7 October 2006. Retrieved from http://www.eastasiaforum.org/2016/10/07/russias-turn-to-the-east/. Retrieved 2 November 2018.

Letterman, C., 'Image of Putin, Russia Suffers Internationally,' Pew Research Centre, 6 December 2018. Retrieved from http://www.pewglobal.org/2018/12/06/image-of-putinrussia-suffers-internationally/.

'North Korea Threatens to Resume Nuclear Development if U.S. Doesn't Lift Sanctions,' $A B C$ News, 3 November 2018. Retrieved from https:/www.nbcnews.com/news/world/northkorea-threatens-resume-nuke-development-over-sanctions-n930761. Retrieved 19 December 2018.

Osborne, Samuel, 'Vladimir Putin Ready to Meet Kim Jong-un to Discuss 'Urgent Issues', says North Korean State Media,' Independent, 15 August 2018. Retrieved from https://www.independent.co.uk/news/world/asia/vladimir-putin-kim-jong-un-north-korearussia-meeting-liberation-day-a8492441.html. Retrieved 26 December 2018. 'Putin Makes First Visit to North Korea,' ABC News, 19 July 2000. Retrieved from https://abcnews.go.com/International/story?id=83114\&page $=1$.

'Putin, Moon agree to support efforts for full denuclearisation,' The Straits Times, 23 June 2018. Retrieved from https://www.straitstimes.com/asia/east-asia/putin-moon-agree-tosupport-efforts-for-full-denuclearisation.

Ramani, S., 'Russia's Love Affair with North Korea,' The Diplomat, 13 February 2017. Retrieved from https://thediplomat.com/2017/02/russias-love-affair-with-north-korea/. 'Russia Allows Thousands of North Korean Workers In,' VoaNews, 3 August 2018. Retrieved from https://www.voanews.com/a/report-russia-north-koreanworkers/4512027.html.

Seligman, Lara and Gramer, Robbie, 'Few Signs of Progress on Denuclearization as U.S., South Korea Cancel Another Major Military Exercise,' Foreign Policy, 19 October 2018. Retrieved from https://foreignpolicy.com/2018/10/19/few-signs-of-progress-ondenuclearization-as-us-south-korea-cancel-another-military-exercise-north-korea-kim-trump/. Retrieved 19 December 2018.

Sharkov, D., 'North Korea Sanctions won't Defeat Kim Jong Un, Says Russian Lawmakers who Visited Pyongyang,' Newsweek, 1 December 2017. Retrieved from

https://www.newsweek.com/north-korea-sanctions-wont-defeat-kim-jong-un-says-russiandelegation-728096.

'Shinzo Abe and Kim Jong-un Could Meet after North Korean Leader Says He's Willing,' South China Morning Post, 14 June 2018. Retrieved from https://www.scmp.com/news/asia/diplomacy/article/2150729/shinzo-abe-and-kim-jong-uncould-meet-after-north-korean-leader. Retrieved 12 December 2018.

Tarabay, Jamie, 'Bad Blood between North Korea and Japan Keeps Abe on the Outs,' CNN News.'28 August 2018. Retrieved from https://edition.cnn.com/2018/08/28/asia/japan-northkorea-relations-intl/index.html. Retrieved 19 December 2018.

The Ministry of Foreign Affairs of the Russian Federation, 'Joint Statement by the Russian and Chinese Foreign Ministries on the Korean Peninsula's Problems,'4 July 2017.

Retrieved from http://www.mid.ru/en/foreign_policy/news/lasset_publisher/cKNonkJE02Bw/content/id/2807662.

Toloraya, Georgy, 'From CVID to CRID: A Russian Perspective,' 38 North, 26 December 2018. Retrieved from https://www.38north.org/2018/12/gtoloraya122618/. Retrieved 26 December 2018.

Whitnall, Adam, 'Japan's Shinzo Abe Says He Could meet Kim Jong-un Face-to-face and 'Break the Shell of Distrust' with North Korea,' The Independent, 26 September 2018. 
Retrieved from https://www.independent.co.uk/news/world/asia/japan-shinzo-abe-kim-jongun-meeting-north-korea-summit-south-a8555316.html.

Wood, L. Todd, 'North Korea's BFF is Russia,' The Washington Post, 7 February 2017.

Retrieved from https://www.washingtontimes.com/news/2017/feb/7/north-korea-puts-russiaatop-friendly-countries-li/. Retrieved 1 December 2018.

Yoe, J. S. 'Lifting sanctions on Rajin-Khasan Project Key to Economic Cooperation with Russia, North Korea,' Korea Herald, 10 July 2018. Retrieved from http://www.koreaherald.com/view.php?ud=20180706000494. 